\title{
The Interaction between Bradyrhizobium Japonicum E109 and Azospirillum Brasilense Az39 Improves Bradyrhizobium-Soybean Symbiosis: The Secrets Behind Co-Inoculation
}

\section{Daniela Torres}

Universidad Nacional de Río Cuarto

Florencia Donadio

Universidad Nacional de Río Cuarto

\section{Gastón López}

Universidad Nacional de Río Cuarto

\section{Romina Molina}

Universidad Nacional de Río Cuarto

\section{Sofia Nievas}

Universidad Nacional de Río Cuarto

\section{Sanja Ćavar Zeljković}

Palacky University

\section{Martín Díaz-Zorita}

Universidad Nacional de La Pampa

Nuria De Diego

Palacky University

Fabricio Dario Cassan ( $\nabla$ fcassan@exa.unrc.edu.ar)

Universidad Nacional de Río Cuarto https://orcid.org/0000-0002-9776-0262

\section{Research Article}

Keywords:

Posted Date: December 8th, 2021

DOI: https://doi.org/10.21203/rs.3.rs-1124833/v1

License: (c) (1) This work is licensed under a Creative Commons Attribution 4.0 International License. Read Full License 


\section{Abstract}

\section{Aims}

The aim of this work was evaluating the interaction between two of the most widely used strains for soybean inoculation in Argentina, B. japonicum E109 (BJE109) and A. brasilense Az39 (AbAz39).

\section{Methods}

Five treatments were performed: (i) uninoculated seeds; (ii) seeds inoculated with $B J E 109$; (iii) seeds inoculated with $A b A z 39$; (iv) seeds co-inoculated with BJE109 and $A b A z 39$ in a 1:1 proportion $(B J \mathrm{JE} 109+A b A z 39)$ at the seeds sowing and (v) seeds inoculated with a 1:1 proportion of BJE109 and AbAz39 (BJE109-AbAz39) $24 \mathrm{~h}$ before seeds sowing. Each treatment was assessed through a seed recovery assay, glasshouse assays and field assays.

\section{Results}

The combination between the two strains improved the ability of $B J E 109$ to survive on soybean seeds after inoculation partially explained by $A b A z 39$ 's capacity to produce diverse biologically active molecules. As a result of the greater rhizobial survival on seeds the nodulation values and symbiosis parameters like nodule number, size and biomass and nodulation percentage also increased. In agreement with these observations, combining BJE109 and $A b A z 39$ at strains the grain yield under field conditions were 13,3 and $17,3 \%$ greater than single $B J E 109$ inoculation.

\section{Conclusions}

These results here show that the pre-culture combining BJE109 and AbAz39 before the inoculation to the soybean seeds has benefits in plant nodulation and hence production, more than individual inoculation with $B J E 109$ or $A b A z 39$, or the immediate co-inoculation of both strains.

\section{Introduction}

Rhizobia are diazotrophic bacteria whose symbiotic interactions with plants from the Fabaceae family result in the formation of specific structures where biological nitrogen fixation (BNF) takes place (Stacey et al. 1992). Some rhizobia, mostly belonging to the genus Bradyrhizobium such as B. japonicum, have been extensively studied in terms of their association with soybean as sustainable alternatives to $\mathrm{N}$-fertilizers (Hungria and Nogueira 2019). On the other hand, Azospirillum are plant-growth promoting bacteria that have attracted particular attention over the last four decades because they improve legume growth, development, and yield when co-inoculated with rhizobia (Bashan and de Bashan 2010). These positive effects are mostly related to Azospirillum's ability to produce phytohormones such as auxins (Crozier et al. 1988; Zimmer and Bothe 1988), cytokinins (Horemans et al. 1986; Cacciari et al. 1989), gibberellins (Bottini et al. 1989; Janzen et al. 1992), abscisic acid and ethylene (Perrig et al. 2007), as well as certain polyamines such as cadaverine (Cassán et al. 2009). The production of auxins, mainly indole-3-acetic acid (IAA), is considered the most important plant-growth promoting mechanism in A. brasilense (Cassán et al. 2014). However, in the case of Bradyrhizobium, the mode of action is still unclear, but many benefits for the plant have been described yet (Jaiswal et al. 2021). The practice of co-inoculation could improve plant performance and the establishment of symbiosis under both controlled and field conditions (Ferri et al. 2017; 
Rodelas et al. 1999; Remans et al. 2008; Cassán et al. 2020). Hungria et al. (2013) and Nogueira et al. (2018) reported an increase in soybean [Glycine $\max \left(\mathrm{L}\right.$.) Merrill] grain yield of over $15 \%$ and $200 \mathrm{~kg}^{\text {.h }} \mathrm{ha}^{-1}$, respectively, through a combination of Bradyrhizobium and Azospirillum as A. brasilense. Studies on soybean coinoculation in Argentina and Brazil also found respective increases in nodulation of over \% (Hungria et al. 2015; Fipke et al. 2016; Galindo et al. 2018) and over 1 \% (Benintende et al. 2010; Ferraris and Couretot 2011, 2013; Morla et al. 2019). Therefore, Azospirillum's ability to produce phytohormones like auxins and cytokinins, and the morphofunctional changes thus induced in the soybean root system (Rondina et al. 2020) enhance the benefits of Bradyrhizobiumsoybean symbiosis (Srinivasan et al. 1996; Molla et al. 2001; Vessey and Buss 2002). In the specific case of $B$. japonicum E109, analysis of its genome revealed the existence of three putative pathways for IAA biosynthesis, but the bacterium is unable to produce it, and can instead degrade both natural and synthetic auxins, including IAA and NAA (Torres et al. 2018). Nevertheless, its biomass and exopolysaccharide production increased with the exogenous addition of IAA to the liquid culture medium where it was grown, which in turn modified its symbiotic behavior with soybean: more nodules were created, and a higher percentage of plants were nodulated (Torres et al. 2018). This supports the idea that it is the active compounds synthesized by Azospirillum which improve nodulation by Bradyrhizobium, yet the mechanisms underlying these effects remain poorly understood. With this in mind, we aimed to elucidate whether symbiosis between Bradyrhizobium and soybean is effective at least in part due the release of active molecules by co-inoculated $A$. brasilense, and to investigate some particularities behind this kind of co-inoculation.

\section{Methodology}

\subsection{Bacterial strains}

Two selected strains were Bradyrhizobium japonicum E109 (BJE109) and Azospirillum brasilense Az39 (AbAz39). Both bacteria were provided by the Institute for Agricultural Microbiology and Zoology in Castelar, Buenos Aires, Argentina (IMYZA for its name in Spanish). These strains are two of the most currently used for inoculant formulations in Argentina and Brazil (Lodeiro 2015; Cassán et al. 2020). Their complete genome sequences have been published by Rivera et al. (2014) and Torres et al. (2015), respectively.

\subsection{Plant material}

Seeds of soybean [Glycine max (L). Merrill] var. "Don Mario 3810 RR" were used for these studies. Quality control parameters were established by the International Seed Test Association (ISTA) (http://www.ista.org).

\subsection{Bacterial growth and seed inoculation}

Seeds were inoculated with individual or combined cultures of BjE109 and $A b A z 39$, according to the treatments described below. The $B J E 109$ titer was adjusted to $5.0 \mathrm{E}+9 \mathrm{cfu} \cdot \mathrm{ml}^{-1}$ obtained at late exponential growth phase in yeast mannitol broth (YEM), as described by Vincent (1970). The AbAz39 titer was adjusted to $5.0 \mathrm{E}+8 \mathrm{cfu}^{\mathrm{ml}} \mathrm{ml}^{-1}$ obtained at late exponential growth phase in Luria broth (LB), as described by Molina et al. (2018). Inoculation doses were adjusted to obtain a final volume of $12 \mathrm{ml}_{\mathrm{kg}} \mathrm{k}^{-1}$ of soybean seeds in all experiments. Five treatments were performed: $i$ ) uninoculated seeds treated with phosphate buffer solution (12 $\mathrm{ml}^{\mathrm{kg}} \mathrm{kg}^{-1}$ ) (control); ii) seeds inoculated with equal volume of $B J E 109$ and phosphate buffer solution (1:1) (BjE109); iii) seeds inoculated with equal volume of $A b A z 39$ and phosphate buffer solution (1:1) (AbAz39); iv) seeds co-inoculated with $B J E 109$ and $A b A z 39$ in a 1:1 ratio (BJE109 + AbAz39), and $v$ ) seeds inoculated with a mix, in a 1:1 ratio, of BJE109 and $A b A z 39$ (BjE109-AbAz39). In the treatment $i v$ ) each microorganism was applied separately during the inoculation process, while for the 
treatment $v$ ) equal volumes of both microorganisms were mixed and maintained at room temperature $\left(25^{\circ} \mathrm{C}\right)$ during $24 \mathrm{~h}$ before the inoculation of the seeds. The incubation time for treatment BJE109-AbAz39 was established following previous results by Torres et al. (2018) about the ability of $B J E 109$ to degrade $40 \mu \mathrm{g} \cdot \mathrm{ml}^{-1} \mathrm{IAA}_{\text {and increase }}$ its own exopolysaccharide (EPS) synthesis and biomass production in YEM culture medium. We also evaluated each microorganism without dilution as a control. After the application of the treatments, the seeds were maintained under sterile laminar air flow conditions at room temperature $\left(25^{\circ} \mathrm{C}\right)$ until analysis.

\subsection{Bacterial count and physiological state}

To determine the number of viable cells $\left(\mathrm{cfu}_{\mathrm{ml}}{ }^{-1}\right.$ ) in each culture or in the mix of both, the microdrop quantification method was performed (Miles and Misra 1938). Plates containing YEM medium (Vincent 1970) or Congo Red medium (Rodríguez Cáceres 1982) were used for BJE109 and $A b A z 39$, respectively. The plates were analyzed after incubation at $30^{\circ} \mathrm{C}$ for 7 days in the case of $B J E 109$ and $37^{\circ} \mathrm{C}$ for 4 days in the case of $A b A z 39$, as described by Cassán et al. (2014) with modifications. In the case of the combined cultures, plates containing both YEM and Congo Red medium were used at temperatures and incubation time mentioned before.

\subsubsection{IAA quantification}

Quantification of IAA was performed by spectrophotometry (Glickmann and Dessaux 1995) and confirmed by HPLC following Torres et al. (2021). Aliquots of $1000 \mu \mathrm{l}$ of bacterial culture were centrifuged at 11,300 $\mathrm{g}$ for $10 \mathrm{~min}$. Next, the samples were filtered $(0.2 \mu \mathrm{m})$ and $500 \mu \mathrm{l}$ of the supernatant were mixed with $500 \mu$ l of Salkowski's reagent and gently shaken in an inverted position at least 10 times. The samples were incubated in the dark for 30 min and absorbance was measured at $530 \mathrm{~nm}$. An aliquot of filtered supernatants was injected into the HPLC equipment as per Torres et al. (2021).

\subsubsection{Exopolysaccharide (EPS) quantification}

Quantification of EPS followed Torres et al. (2018). Briefly, the samples were centrifuged and then the supernatants were filtered and treated with DNase I and proteinase K. The EPSs were precipitated with ethanol and dried at room temperature before being resuspended in deionized water. Total carbohydrate content (EPS. $\mathrm{mg}^{-1}$ biomass) was measured through the phenol-sulfuric acid method, with glucose as a standard.

\subsection{Seed recovery assays}

Soybean seeds that had been either inoculated or co-inoculated (section 3.3) were maintained in aseptic environmental conditions at room temperature $\left(\cong 25^{\circ} \mathrm{C}\right)$ for 4 hours before initial analysis and then 6 days before a second analysis, as described by Torres et al. (2018). Bacterial cell count and survival factor percentage (SFP) were determined for BJE109 and AbAz39 following the criteria by Penna et al. (2011). The plates were incubated at $30^{\circ} \mathrm{C}$ for 7 days in the case of $B J E 109$ and at $37^{\circ} \mathrm{C}$ for 4 days in that of $A b A z 39$. Additional counts were performed on uninoculated seeds (control). Results are expressed as the number of viable cells recovered from the seeds (cfu.seed $^{-1}$ ) and the survival factor percentage (SFP) as the cfu.seed ${ }^{-1} 4 \mathrm{~h}$ after inoculation, according to Penna et al. (2011).

\subsection{Greenhouse assays}

The treated soybean seeds from each treatment listed in section 3.3 were sown in plastic pots (300 ml volume capacity) containing vermiculite as a solid substrate. Three seeds per pots were planted in six pots and irrigated with sterile $\mathrm{N}$-free Hoagland's solution (25\% v/v) (Hoagland and Boyer 1936) keeping them at field capacity during the 
study. The seedlings were maintained inside a growth chamber for 21 days with a photoperiod of 16/8 $\mathrm{h}$ light regime, $30 / 20^{\circ} \mathrm{C}$ temperature and a relative humidity of $80 \%$. At the end of the experiment, the following parameters were measured: (1) number of nodules located on main root per plant (MRN), (2) number of nodules located on secondary roots per plant (SRN), (3) total number of nodules on roots per plant (RN), (4) percentage of plants with three or more nodules on the main root (BT), following Burton et al. (1976), and (5) shoot and root dry weight (SDW and RDW).

\subsection{Field assay}

A field experiment was performed during the 2018/19 cropping season close to 9 de Julio, Buenos Aires province, Argentina $\left(38^{\circ} 28^{\prime} \mathrm{S}, 60^{\circ} 57^{\prime} \mathrm{W}\right)$. The soil was classified as silty-loam Typic Argiduoll under agriculture with wheat (Triticum aestivum L.), soybean and maize (Zea mays $\mathrm{L}$ ) in rotation since more than 20 years. Before the sowing, topsoil samples $(0-20 \mathrm{~cm})$ were collected and analyzed in terms of water $\mathrm{pH}(5,9)$; organic matter content $(25,4$ g. $\left.\mathrm{dm}^{3}\right)$; cation exchangeable capacity (CEC) (3,74); C (5,34 g.dm³); extractable P, according to Bray and Kurtz (1945), $\left(3,1 \mathrm{mg} \cdot \mathrm{dm}^{3}\right) ; \mathrm{S}^{-\mathrm{SO}_{4}}\left(4,3 \mathrm{mg} \cdot \mathrm{dm}^{3}\right)$; extractable cations [Ca $\left(6,42 \mathrm{cmol}_{\mathrm{c}} \cdot \mathrm{dm}^{3}\right) ; \mathrm{Mg}\left(1,28 \mathrm{cmol}_{\mathrm{C}} \cdot \mathrm{dm}^{3}\right) ; \mathrm{K}(1,12$ $\left.\mathrm{cmol}_{\mathrm{C}} \cdot \mathrm{dm}^{3}\right)$ and $\left.\mathrm{Na}\left(0,24 \mathrm{cmol}_{\mathrm{c}} \cdot \mathrm{dm}^{3}\right)\right]$; extractable $\mathrm{Zn}\left(1,24 \mathrm{cmol}_{\mathrm{C}} \cdot \mathrm{dm}^{3}\right)$ and extractable $\mathrm{Mn}\left(15,8 \mathrm{mg} \cdot \mathrm{dm}^{3}\right)$ according to Lindsay and Norwell (1978); extractable Cu $\left(0,77 \mathrm{mg} \cdot \mathrm{dm}^{3}\right)$; extractable Fe $\left(68,4 \mathrm{mg} \cdot \mathrm{dm}^{3}\right)$ and extractable B $(0,60$ $\mathrm{mg} \cdot \mathrm{dm}^{3}$ ). The regular crop calendar and standard field practices were followed. On October 20th, 2018, treated seeds according to the treatments described in section 3.3 were directly sown at a rate of $18 \mathrm{seeds} \mathrm{m}^{-1}$ and fertilized in furrow with $60 \mathrm{~kg} \cdot \mathrm{ha}^{-1}$ of triple superphosphate (0:46:0). The seeds were not chemically treated with fungicides, insecticides, micronutrients or other products. The experiment was placed in randomized blocks with six replicates per treatment. The plots consisted of 4 lines of $8.0 \mathrm{~m}$ in length width spaced $0.52 \mathrm{~m}$ apart. The crops were kept free of weed, pest and diseases competence using regular integrated management practices when needed.

Approximately 7 weeks after the emergence of the crops, in a sub-sample of 20 plants per treatment at the v6 growth stage (Ritchie et al. 1994), the nodule number, its location, size and dry weight were evaluated. Also, the plant biomass (weight) and intensity of the green color in SPAD meter units of the upper leaves (Markwell et al. 1995) were measured. After reaching crop physiological maturity (R8) on March 11th, 2019, the central rows of the plots (1 $\mathrm{m}^{2}$ ) were manually harvested. The grain yield was expressed at $140 \mathrm{~g} \mathrm{~kg}^{-1}$ of moisture content. The single grain weight and the nitrogen concentration in the grains was measured to estimate the protein grain content.

\subsection{Statistical analysis}

The treatments for greenhouse experiments were performed in with six replicates per treatment, while the field experiment was placed in randomized blocks with six replicates per treatment. The values shown represent the mean \pm standard error of mean (SEM). The data was analyzed for variance factor differences using ANOVA followed by Tukey's post hoc analysis at $p<0.05$. The statistical analyses were made using the PRISM V 4.0 statistical package for Windows ${ }^{\circledR}$. The matrix correlation was performed using RStudio software (version 1.4.1717, (C) 2009-2021 Rstudio, PBC) using the packages factoextra and corrplot.

\section{Results}

\subsection{Bacterial count and physiological state}

To define an experimental model based on the interaction between BjE109 and AbAz39, mixes of different proportions of each strain (1:9, 1:1 and 9:1) were evaluated for the EPS production, microbial biomass and IAA concentration in the culture medium after $24 \mathrm{~h}$ interaction. The results of this assessment are showed in 
Supplementary material (Table S1). An equal proportion of each microorganism (1:1) was selected, since it rendered the highest production of biomass and EPS, the two parameters of our main interest in this experiment according to Torres et al. (2018).

Table 1 summarizes the cell number, EPS content, IAA concentration and biomass production of $B J E 109$ and $A b A z 39$ cultures obtained individually (control), in combination (1:1) with buffer phosphate (PB), or with both bacteria incubated for 15 minutes (T0) or $24 \mathrm{~h}$ (T24).

Table 1

Cell number, EPS production, IAA concentration and biomass production of BJE109 and AbAz39 cultures obtained individually (control), in combination (1:1) with buffer phosphate (PB), or with both bacteria incubated for 15 minutes (T0) or $24 \mathrm{~h}$ (T24). Different letters represent significant differences according to Tukey test $p<0.05$.

\begin{tabular}{|c|c|c|c|c|c|}
\hline Treatment & $\begin{array}{l}\log _{10} \\
\text { cell number } \\
A b A z 39 \\
\text { cfu.ml-1 }\end{array}$ & $\begin{array}{l}\log _{10} \\
\text { cell number } \\
B J \mathrm{~J} 109 \mathrm{YEM} \\
\text { cfu.ml }\end{array}$ & $\begin{array}{l}\text { EPS } \\
\mu \mathrm{g} . \mathrm{ml}^{-1}\end{array}$ & $\begin{array}{l}\text { IAA } \\
\mu \mathrm{g} . \mathrm{ml}^{-1}\end{array}$ & $\begin{array}{l}\text { Biomass } \\
\text { production } \\
\mathrm{OD}_{595}\end{array}$ \\
\hline \multirow[t]{2}{*}{ AbAz39-Control } & $8.710 \pm 0.012^{a}$ & * & $1.05 \pm 0.09^{e}$ & $15.23 \pm 1.21^{\mathrm{a}}$ & $1.83 \pm 0.12^{d}$ \\
\hline & $5.12 e+8$ & & & & \\
\hline \multirow[t]{2}{*}{ BJE109-Control } & * & $9.710 \pm 0.013^{a}$ & $3.45 \pm 0.10^{b}$ & * & $2.41 \pm 0.04^{b}$ \\
\hline & & $5.12 e+9$ & & & \\
\hline \multirow[t]{2}{*}{ BJE109 + PB (1:1) - T0 } & * & $9.387 \pm 0.023^{b}$ & $1.87 \pm 0.22^{d}$ & * & $1.33 \pm 0.18^{e}$ \\
\hline & & $2.44 e+9$ & -45.79 & & -44.81 \\
\hline \multirow[t]{2}{*}{ AbAz39 + PB (1:1) - T0 } & $8.377 \pm 0.007^{b}$ & * & $0.57 \pm 0.12^{f}$ & $8.62 \pm 2.03^{b}$ & $1.01 \pm 0.2^{f}$ \\
\hline & $2.38 \mathrm{e}+8$ & & -45.71 & -43.40 & -44.80 \\
\hline \multirow{2}{*}{$\begin{array}{l}\text { BJE109 + AbAz39 (1:1) } \\
\text { - T0 }\end{array}$} & $8.390 \pm 0.019^{b}$ & $9.399 \pm 0.026^{b}$ & $2.64 \pm 0.14^{c}$ & $7.54 \pm 1.38^{b}$ & $2.21 \pm 0.09^{c}$ \\
\hline & $2.45 e+8$ & $2.51 e+9$ & +8.19 & -12.52 & -5.55 \\
\hline \multirow{2}{*}{$\begin{array}{l}\text { BJE109 + AbAz39 (1:1) } \\
-\mathrm{T} 24\end{array}$} & $8.403 \pm 0.033^{b}$ & $9.416 \pm 0.015^{b}$ & $5.73 \pm 0.17^{a}$ & * & $2.68 \pm 0.07^{a}$ \\
\hline & $2.53 e+8$ & $2.61 \mathrm{e}+9$ & & & \\
\hline
\end{tabular}

Production of EPS and IAA by AbAz39 was as expected for the biomass and cell count measured in the growth medium, as well as with reference to previous studies under similar conditions (Rivera et al. 2018; Molina et al. 2020). BjE109's production of EPS was three times higher than that of AbAz39 and no IAA was detected in its growth medium, as reported before (Torres et al. 2018). When the pure cultures of each strain were mixed with phosphate buffer (1:1), the values of all the parameters assessed decreased around $50 \%$ with respect to the undiluted cultures, so synergic or antagonistic interactions with the buffer should not be ruled out. The 1:1 co-inoculation of both strains at TO led to a $29.1 \%$ and $39.8 \%$ increase in EPS and biomass, respectively, with respect to the BJE109 culture diluted in phosphate buffer (1:1), which could be ascribed to the presence of the growth medium for $A b A z 39$. Contrarily, in the co-inoculation the IAA levels were 14.3\% lower than in the AbAz39 culture diluted in phosphate buffer (1:1), and this may be attributed to BJE109's ability to degrade the hormone. When the T24 mix was examined, 
the values of EPS content and biomass were still increased with three and two times higher than in the BJE109 phosphate buffer culture, respectively, likely due to the interaction between both bacteria. IAA concentration, meanwhile, had fallen below detectable levels because of BJE109's degrading activity.

\subsection{Seed recovery assays}

Table 2 summarized the values for cell recovered and survival factor on seeds treated with the strains individually or in combination.

Table 2

Cell recovery and survival factor (SFP) of BjE109 and AbAz39 4 hours or 6 days after being inoculated on soybean seeds, either individually (control) or in combination (1:1) after 15 minutes (T0) or 24 hours (T24) of interaction. Different letters represent significant differences according to Tukey test $p<0.05$.

\begin{tabular}{|c|c|c|c|c|c|c|c|c|}
\hline \multirow{3}{*}{$\begin{array}{l}\text { Strains and } \\
\text { Treatments }\end{array}$} & \multicolumn{4}{|l|}{ BJE109 } & \multicolumn{4}{|l|}{ AbAz39 } \\
\hline & 4 hours & & 6 days & & 4 hours & & 6 days & \\
\hline & $\begin{array}{l}\text { cfu.seed }^{-1} \\
\log _{10}\end{array}$ & $\begin{array}{l}\text { SFP } \\
(\%)\end{array}$ & $\begin{array}{l}\text { cfu.seed }^{-1} \\
\log _{10}\end{array}$ & $\begin{array}{l}\text { SFP } \\
(\%)\end{array}$ & $\begin{array}{l}\text { cfu.seed }{ }^{-1} \\
\log _{10}\end{array}$ & $\begin{array}{l}\text { SFP } \\
(\%)\end{array}$ & $\begin{array}{l}\text { cfu.seed }^{-1} \\
\log _{10}\end{array}$ & $\begin{array}{l}\text { SFP } \\
(\%)\end{array}$ \\
\hline Naked seeds & * & $\star$ & * & * & * & * & * & * \\
\hline AbAz39-Control & * & * & * & * & $\begin{array}{l}7,43 e+3 \\
3,870 \pm 0,041^{b}\end{array}$ & 4,87 & $<1 \mathrm{e}+3$ & nd \\
\hline BJE109-Control & $\begin{array}{l}2,23 e+5 \\
5,349 \pm 0,011^{c}\end{array}$ & 14.54 & $\begin{array}{l}1,15 e+4 \\
4,071 \pm 0,16^{c}\end{array}$ & 0.80 & * & * & * & * \\
\hline $\begin{array}{l}\text { BJE109 + } \\
\text { AbAz39 (1:1) - } \\
\text { T0 }\end{array}$ & $\begin{array}{l}3,05 e+5 \\
5,485 \pm 0,009^{b}\end{array}$ & 19.88 & $\begin{array}{l}7,20 e+4 \\
4,856 \pm 0,004^{b}\end{array}$ & 4.69 & $\begin{array}{l}1,04 e+4 \\
4,016 \pm 0,054^{a}\end{array}$ & 5,93 & $<1 \mathrm{e}+3$ & nd \\
\hline $\begin{array}{l}\text { BJE109 + } \\
\text { AbAz39 (1:1) - } \\
\text { T24 }\end{array}$ & $\begin{array}{l}5,47 e+5 \\
5,349 \pm 0,011^{a}\end{array}$ & 35.36 & $\begin{array}{l}1,35 e+5 \\
5,013 \pm 0,042^{a}\end{array}$ & 8.81 & $\begin{array}{l}1,16 e+4 \\
4,062 \pm 0,055^{a}\end{array}$ & 6,50 & $<1 \mathrm{e}+3$ & nd \\
\hline
\end{tabular}

No microorganisms compatible with the ones used in this study could be detected on untreated seeds. On seeds inoculated with $A b A z 39$, viable bacteria and the survival factor percentage (4.87\%) could be measured only $4 \mathrm{~h}$ after inoculation and were lower than those obtained for seeds inoculated with BjE109. The survival factor $4 \mathrm{~h}$ post inoculation was $14.54 \%$ and $0.8 \%$ after six days, i.e., survival was longer despite the significant fall since the 4-day measurement. The $4 \mathrm{~h}$ post-inoculation value for BJE109 was ramped up by $36.77 \%$ when it was inoculated at the same time as $A b A z 39$ in a 1:1 proportion (T0), while the $6 \mathrm{~d}$ post-inoculation value rose almost two times under the same conditions. Co-inoculation at T0 measured $4 \mathrm{~h}$ after inoculation also increased $A b A z 39$ 's survival by $25 \%$. The pattern observed here suggests both strains have better chances of surviving when they can interact among each other on the seeds.

In the 1:1 mix inoculated at T24, the survival rate for BJE109 rose approximately $75 \% 4 \mathrm{~h}$ post inoculation and $90 \% 6$ $\mathrm{d}$ post-inoculation with respect to the values obtained at T0. The differences were bigger if these results were 
compared to the individual BjE109 inoculation, reaching 2-fold and 10-fold higher values, respectively. The T24 mix, moreover, increased $A b A z 39$ 's count and survival by around 9\% with respect to the T0 treatment, and 33\% with respect to the strain inoculated on its own. These results confirmed the mutual benefit relationship between the two strains for longer survival.

Figure 1 shows the recovery at different post-inoculation times of viable BjE109 cells on seeds inoculated with the strain on its own or in combination with $A b A z 39$ (1:1), $15 \mathrm{~m}$ after the mix was prepared (T0) o $24 \mathrm{~h}$ later (T24). Grey bars represent recovery after treatment with the T24 mix, considered the most successful as regards the survival values up to 15 days after inoculation compared to individual treatment, and 9 days compared to T0. When BJE109 was inoculated on its own, recovery was indeed possible but at very low values and only up to 6 days after inoculation. The difference between the T24 and T0 treatments was at its peak immediately after inoculation, and still observable though ever decreasing between day 3 and day 15 after inoculation.

\subsection{Greenhouse assays}

The data shown in the Table 3 contains the growth and nodulation values for soybean seedlings 4 hours or 6 days after inoculation with either BJE109 or AbAz39, individually, or the combination of both at T0 or T24. 
Table 3

Effects on soybean seedling growth and nodulation 4 hours after being inoculated with $B J \mathrm{E} 109$ and $A b \mathrm{Az} 39$ individually (control) or in combination (1:1) after $15 \mathrm{~min}$ (T0) or $24 \mathrm{~h}$ (T24) of interaction. Different letters represent significant differences according to Tukey test $\mathrm{p}<0.05$.

\begin{tabular}{|c|c|c|c|c|c|c|}
\hline Treatments & MRN & SRN & RN & SDW & RDW & BT \\
\hline & \multicolumn{6}{|c|}{4 hours after inoculation } \\
\hline Naked seeds & * & * & * & $0.169 \pm 0.005^{d}$ & $0.069 \pm 0.005^{\mathrm{e}}$ & * \\
\hline AbAz39-Control & * & * & * & $0.172 \pm 0.008^{d}$ & $0.079 \pm 0.003^{d}$ & * \\
\hline BJE109-Control & $13.21 \pm 0.42^{c}$ & $11.43 \pm 0.33^{c}$ & $24,64 \pm 0.75^{c}$ & $0.264 \pm 0.007^{c}$ & $0.104 \pm 0.009^{c}$ & $84.0 \%$ \\
\hline \multirow{2}{*}{$\begin{array}{l}\text { BJE109 + AbAz39 } \\
(1: 1)-\text { T0 }\end{array}$} & $14.58 \pm 0.36^{b}$ & $12.75 \pm 0.19^{b}$ & $27,33 \pm 0.55^{b}$ & $0.289 \pm 0.006^{b}$ & $0.127 \pm 0.011^{\mathrm{a}}$ & $91.0 \%$ \\
\hline & +10.3 & +11.54 & +10.9 & +9.4 & +22.1 & +7.0 \\
\hline \multirow{3}{*}{$\begin{array}{l}B J E 109+A b A z 39 \\
(1: 1) \text { T24 }\end{array}$} & $15.44 \pm 0.29^{a}$ & $13.92 \pm 0.61^{a}$ & $29,36 \pm 0.9^{a}$ & $0.301 \pm 0.005^{a}$ & $0.119 \pm 0.003^{b}$ & $96.0 \%$ \\
\hline & +16.8 & +21.7 & +19.15 & +14.01 & +14.42 & +12.0 \\
\hline & \multicolumn{6}{|c|}{6 days after inoculation } \\
\hline Natural seeds & * & * & * & $0.137 \pm 0.006^{d}$ & $0.041 \pm 0.011^{e}$ & * \\
\hline AbAz39-Control & * & * & * & $0.145 \pm 0.012^{d}$ & $0.057 \pm 0.004^{d}$ & * \\
\hline BJE109-Control & $6.35 \pm 0.39^{c}$ & $13.21 \pm 0.52^{c}$ & $19,56 \pm 0.91^{c}$ & $0.218 \pm 0.004^{c}$ & $0.104 \pm 0.003^{b}$ & $58.0 \%$ \\
\hline $\begin{array}{l}\text { BJE109 + AbAz39 } \\
(1: 1)\end{array}$ & $7.44 \pm 0.19^{b}$ & $16.01 \pm 0.39^{b}$ & $23,45 \pm 0.98^{b}$ & $0.237 \pm 0.008^{b}$ & $0.123 \pm 0.09^{a}$ & $67.0 \%$ \\
\hline TO & +17.16 & +21.19 & +19.88 & +8.71 & +18.26 & +9.0 \\
\hline BJE109-AbAz39 (1:1) & $8.16 \pm 0.23^{a}$ & $17.97 \pm 0.70^{a}$ & $26,13 \pm 0.93^{a}$ & $0.245 \pm 0.003^{a}$ & $0.117 \pm 0.008^{c}$ & $74.0 \%$ \\
\hline T24 & +28.5 & +36.03 & +22.95 & +12.38 & +12.5 & +16.0 \\
\hline
\end{tabular}

No nodules were formed on the uninoculated controls, which corroborates the absence of Bradyrhizobium in the substrate. The significant improvement in both belowground (RDW) and aboveground biomass (SDW) of the plants inoculated with either BJE109 or AbAz39 evidence the positive effects of inoculation, at any of the two times assessed. Meanwhile, the combined 1:1 inoculation at T0 produced 10.3\% more nodules on the main root (MRN) and $11.5 \%$ more on the secondary roots (SRN) $4 \mathrm{~h}$ after inoculation than the individual treatment with $B J \mathrm{E} 109$. The plant biomass was also benefited with an increase of shoot (SDW) and root (RDW) dry weight of $9.4 \%$ and $22.1 \%$, respectively. At T24, the seed inoculation using the mix of strains also improved the values of other parameters compared to T0: $6.5 \%$ in MRN; $10.2 \%$ in SRN; $9.8 \%$ in root nodules per plant (RN); $4.7 \%$ in SDW and $5.0 \%$ in the percentage of nodulated plants (BT), whereas the RDW decreased by $8.0 \%$. The results from the comparison of the two co-inoculation treatments demonstrates that allowing the interaction between the two strains during at least 24 hours before inoculation (T24) is beneficial for the nodulation and the plant growth compared to T0 and the treatment only with BJE109. Although all measurements describing the symbiosis and the plant growth significantly dropped 6 days after inoculation ( $6 \mathrm{dpi}$ ), both co-inoculation treatments continued outperforming the one with 
BjE109 alone, a further indication of the advantages of co-inoculation over the long term. In a similar manner to the earlier determinations, MRN, SRN and RN were $11.3 \%, 11.8 \%$ and $3.1 \%$ higher, respectively, 6 dpi with the T24 mix than at T0. SDW and BT were also higher (3.7\% and 7.0\%). The co-inoculation at T0 could only outperform the T24 treatment when it came to RDW, both 4 dpi and 6 dpi.

The Fig. 2 shows the nodulation in the roots of soybean seedlings developed from seed inoculated with either BJE109 or AbAz39, individually, or the combination of both at T0 or T24. Both MRN and RN significantly decreased over time regardless of the treatments. Nevertheless, the results were significantly better up to 15 days after inoculation (15 dpi) with the T24 mix than with the treatment at T0 or with BJE109. The co-inoculation at T0 outperformed the seed inoculation with the individual strain, except on day 3 (3 dpi) when there were no statistically significant differences between both treatments. In summary, both mixtures, but particularly the one inoculated at T24, were able to revert the decreasing nodulation trend over time.

\subsection{Field assay}

The data in the Table 4 show how, under field conditions, the inoculation with either BJE109 or $A b A z 39$, individually, or the combination of both at T0 or T24 modified the growth of soybeans crops and its symbiosis.

Table 4

Effects, under field conditions, on the plant growth and Bradyrhizobium-soybean symbiosis (nodulation) of the inoculation with $B J E 109$ and $A b A z 39$, either individually (control) or in combination (1:1) after $15 \mathrm{~min}$ (T0) or $24 \mathrm{~h}$ (T24) of interaction. Different letters represent significant differences according to Tukey test $p<0.05$.

\begin{tabular}{|c|c|c|c|c|c|c|c|c|c|c|}
\hline & \multicolumn{7}{|l|}{ Nodules } & \multicolumn{3}{|l|}{ Plants } \\
\hline & \multirow[t]{2}{*}{ Biomass } & \multicolumn{3}{|c|}{ Size range } & \multicolumn{3}{|l|}{ Number } & \multirow{2}{*}{$\begin{array}{l}\text { Shoot } \\
\text { biomass }\end{array}$} & \multirow{2}{*}{$\begin{array}{l}\text { Root } \\
\text { biomass }\end{array}$} & \multirow{2}{*}{$\begin{array}{l}\text { Green } \\
\text { color }\end{array}$} \\
\hline & & I & II & III & MR & SR & Total & & & \\
\hline $\begin{array}{l}\text { Naked } \\
\text { seeds }\end{array}$ & $1.038^{d}$ & $10.0^{d}$ & $17.6^{d}$ & $36.9^{d}$ & $36.1^{d}$ & $28.3^{e}$ & $64.4^{e}$ & $20.375^{d}$ & $6.563^{c}$ & $45.3^{a}$ \\
\hline \multirow{2}{*}{$\begin{array}{l}\text { AbAz39- } \\
\text { Control }\end{array}$} & $1.112^{\mathrm{C}}$ & $12.0^{\mathrm{d}}$ & $19.0^{\mathrm{d}}$ & $42.0^{c}$ & $37.3^{d}$ & $35.7^{d}$ & $73.0^{d}$ & $21.270^{d}$ & $6.923^{c}$ & $45.8^{a}$ \\
\hline & $+7.1 \%$ & & & & $+3.2 \%$ & $+26.3 \%$ & $+13.4 \%$ & $+4.3 \%$ & $+5.4 \%$ & \\
\hline $\begin{array}{l}\text { BJE109- } \\
\text { Control }\end{array}$ & $1.425^{b}$ & $24.8^{c}$ & $38.6^{c}$ & $67.1^{\mathrm{b}}$ & $59.6^{c}$ & $70.9^{c}$ & $130.5^{c}$ & $26.780^{c}$ & $7.775^{b}$ & $45.9^{a}$ \\
\hline \multirow{2}{*}{$\begin{array}{l}\text { BJE109 } \\
+ \\
\text { AbAz39 } \\
(1: 1)- \\
\text { T0 }\end{array}$} & $1.631^{\mathrm{a}}$ & $38.5^{\mathrm{b}}$ & $54.8^{a}$ & $63.1^{\mathrm{b}}$ & $72.0^{b}$ & $84.4^{b}$ & $156.4^{b}$ & $30.250^{b}$ & $8.575^{a}$ & $45.8^{a}$ \\
\hline & $+14.4 \%$ & & & & $+20.8 \%$ & $+19.0 \%$ & $+19.8 \%$ & $+12.9 \%$ & $+10.2 \%$ & \\
\hline \multirow{2}{*}{$\begin{array}{l}\text { BJE109 } \\
+ \\
\text { AbAz39 } \\
(1: 1)- \\
\text { T24 }\end{array}$} & $1.685^{\mathrm{a}}$ & $49.4^{\mathrm{a}}$ & $50.7^{b}$ & $70.2^{a}$ & $78.5^{a}$ & $91.8^{a}$ & $188.3^{a}$ & $31.501^{a}$ & $8.975^{a}$ & $46.1^{a}$ \\
\hline & $+18.2 \%$ & & & & $+31.6 \%$ & $+29.4 \%$ & $+30.5 \%$ & $+17.6 \%$ & $+15.4 \%$ & \\
\hline
\end{tabular}

Nodules, Biomass (g.plant $\left.{ }^{-1}\right)$, size range: I: $(>5 \mathrm{~mm})$; II: $(2-5 \mathrm{~mm})$; III: $(<2 \mathrm{~mm})$; Nodules number: MR: main root; SR: secondary roots; Plant dry biomass: shoot biomass (g. plant ${ }^{-1}$ ); root biomass (g. plant ${ }^{-1}$ ), upper leaves green color intensity (SPAD units)

In the plants developed from seeds inoculated with BjE109, the nodule biomass per plant increased 37.3\% compared to uninoculated seeds. When the inoculation was performed with AbAz39 the nodule biomass per plant was $7.1 \%$ 
greater than in those developed from uninoculated seeds. After the combination of $B J E 109$ and $A b A z 39$, the biomass of the nodules was greater than the observed when single BJE109 or AbAz39 treatments were applied to the seeds. The co-inoculation at T0 also increased $12.9 \%$ the soybean shoot biomass compared to the individual inoculation with BjE109 and $17.6 \%$ in the case T24 without differences between both combined treatments. The nodule biomass varied from $1.038 \mathrm{~g}$ without inoculation to $1.631 \mathrm{~g}$ with co-inoculation at T0 and $1.685 \mathrm{~g}$ at T24 representing an increase of $14.4 \%$ and $18.2 \%$ respectively. In the treatment only with BjE109 this value was $1.425 \mathrm{~g}$ and represented an increase of $7.1 \%$ in comparison to the control without inoculation. In terms of nodule size, the T24 induced the highest number of nodules greater than $5 \mathrm{~mm}$ (range I) and smaller than $2 \mathrm{~mm}$ (range III), while the T0 treatment rendered more nodules from 2 to $5 \mathrm{~mm}$ (range II). In both cases, the plants developed from the co-inoculation treatments produced more nodules within all three ranges than the single inoculation with BJE109. At the same time, this last treatment improved the number of nodules in the ranges I and II than those obtained with the single inoculation with $A b A z 39$ but reduced those in the range III. Nodule size after the treatment with $A b A z 39$ was like the uninoculated control in ranges I and II, and this fact suggests the capability of Azospirillum to interact with the rhizobia of the soil promoting nodulation.

The nodule number and its location in the root system of the plants was also assessed. The highest MRN, SRN and total number of nodules (TN) was observed after co-inoculation with the 1:1 mix at T24. The SRN and TN were significantly higher after inoculation with $A b A z 39$ on its own than in the control. On the other hand, the relative difference for MRN, was not significant, which might indicate a positive interaction between Azospirillum and the native bradyrhizobia in the soil where the assay was carried out. The shoot and the root biomass of the plants was also significantly increased after the co-inoculation (Table 4). However, whereas the SDW was significantly higher in those plants co-inoculated at T24 compared to T0, these differences were not observed for RDW. The intensity of the green color of the upper leaves measured in SPAD index units did not show differences among the treatments.

Insertion Table 5 
Table 5

Effects on crop productivity under field conditions of soybean crops developed from seeds individually inoculated (Control) or co-inoculated (1:1) after 15 min (T0) or $24 \mathrm{~h}$ interaction (T24) with BjE109 and AbAz39. Different letters represent significant differences according to Tukey test $\mathrm{p}<0.05$.

\begin{tabular}{|c|c|c|c|c|c|c|}
\hline & $\begin{array}{l}\text { Plant stand at } \\
\text { harvest } \\
\text { (plants. } \mathrm{m}^{-1} \text { ) }\end{array}$ & $\begin{array}{l}\text { Grain } \\
\text { moisture at } \\
\text { harvest } \\
\left(\mathrm{g} \cdot \mathrm{kg}^{-1}\right)\end{array}$ & $\begin{array}{l}\text { Single grain } \\
\text { weight } \\
\left(\mathrm{mg}^{\text {grain }}{ }^{-1}\right)^{*}\end{array}$ & $\begin{array}{l}\text { Total } \\
\text { grain } \mathbf{N} \\
\left(\mathrm{mg} \cdot \mathrm{g}^{-1}\right)\end{array}$ & $\begin{array}{l}\text { Total grain } \\
\text { Protein } \\
\left(\mathrm{mg} \cdot \mathrm{g}^{-1}\right)\end{array}$ & $\begin{array}{l}\text { Grain yield } \\
\left(\mathrm{kg} \mathrm{ha}^{-1}\right)^{\star}\end{array}$ \\
\hline Naked seeds & $14.7^{\mathrm{a}}$ & $182^{a}$ & $181.8^{a}$ & $6.24^{c}$ & $34,2^{c}$ & $4027^{d}$ \\
\hline \multirow[t]{2}{*}{ AbAz39-Control } & $14.9^{a}$ & $181^{a}$ & $182.4^{\mathrm{ab}}$ & $6.23^{c}$ & $35,1^{c}$ & 4099d \\
\hline & & & $+0.3 \%$ & $+0.9 \%$ & $+2.5 \%$ & $+1.7 \%$ \\
\hline BJE109-Control & $14.1^{\mathrm{a}}$ & $182^{a}$ & $181.7^{b}$ & $6.48^{b}$ & $38,2^{b}$ & $4318^{c}$ \\
\hline \multirow[t]{2}{*}{$\begin{array}{l}\text { BJE109 + AbAz39 } \\
(1: 1)-\text { T0 }\end{array}$} & $14.6^{a}$ & $181^{a}$ & $183.6^{a b}$ & $6.52^{\mathrm{a}}$ & $39,1^{\mathrm{ab}}$ & $4563^{b}$ \\
\hline & & & $+1.0 \%$ & $+0.7 \%$ & $+2.4 \%$ & $+13.3 \%$ \\
\hline \multirow[t]{2}{*}{$\begin{array}{l}B J E 109+A b A z 39 \\
(1: 1)-T 24\end{array}$} & $14.8^{a}$ & $187^{a}$ & $184.9^{a}$ & $6.60^{a}$ & $40,1^{a}$ & $4713^{a}$ \\
\hline & & & $+1.7 \%$ & $+1.8 \%$ & $+4.9 \%$ & $+17.03 \%$ \\
\hline
\end{tabular}

As can be seen in Table 5, the greater nodulation and biomass production observed, under field conditions, with the co-inoculation of AbAz39 and BJE109 at T24 (Table 4) correlated with a higher soybean grain yield. The treatment of co-inoculation at T24 favored a grain yield production $17.0 \%$ greater than the control without inoculation, $15.0 \%$ than with the single inoculation with $A b A z 39,9.1 \%$ than only with $B J E 109$, and $3.3 \%$ than the co-inoculation at T0. There were no mean differences in the single grain weight and in the concentration of $\mathrm{N}$ in the grains suggesting that most of the yield differences were related with better growth conditions among all the growing season and keeping an efficient biological $\mathrm{N}$ fixation.

Based on the integrated analysis of the results, we interpret that the co-inoculation with $A b A z 39$ and $B j E 109$ has many advantages in soybean plant growth so improves the quality and the quantity of the nodulation and the crop grain yield. To validate this interpretation of the results we performed a correlation matrix representing the evaluated parameters from all treatments (Fig. 3). As results, we obtained that all the crop growth and yield related parameters, except for the green intensity of the upper leaves, significantly correlated with the nodulation parameters. Also, it is observed that the plant growth has more influence on the number of nodules and its location than in their single size.

\section{Discussion}

In plants, co-inoculation is performed with a combination of different bacterial genera or species with the aim to modify plant growth and development synergistically. A great number of non-symbiotic or free-living bacteria are known to promote symbiosis in legumes when co-inoculated with rhizobia. A recent analysis of over 300 cases of positive plant responses to Azospirillum in 12 countries (Cassán and Díaz-Zorita 2016) found that the rise in its coinoculation with rhizobia led to a $6.6 \%$ increase in legume yield over rhizobia-only treatments. In the last decades, 
research in Argentina and Brazil has assessed the benefits of this kind of co-inoculation for the cultivation of soybean (Hungria et al. 2013; Hungria et al. 2015; Queiroz Rego et al. 2018; Deak et al. 2020; Moretti et al. 2020; Rondina et al. 2020). The combined use of rhizobia and Azospirillum for the growth of legumes, mainly soybean, goes back to the 1990s. Inoculants containing Bradyrhizobium and A. brasilense were authorized for commercial use on soybean in Brazil in 2013, and have shown to increase grain yields (Hungria et al. 2013; Hungria and Nogueira 2019; dos Santos et al. 2019). There are about eighty registered products in South America whose active agent is $A$. brasilense, with AbAz39 strain being the most frequent (Cassán et al. 2020). Moreover, in Argentina there are over 15 commercial inoculants for soybean formulated based on $B J E 109$ (the most widely recommended strain for inoculation), for which co-inoculation with $A$. brasilense is also advised. Currently, there is an increasing use of Azospirillum-based inoculants in Brazil soybean and beans (Phaseolus vulgaris). In the state of Parana, for instance, the use of co-inoculation rose by almost 30\% between 2016 and 2018 (Prando et al. 2016; 2018). Despite the data available regarding commercial and agricultural performance, little is known about the exact reasons why this type of co-inoculation improves plant growth. And furthermore, if these responses are do to interactions between Azospirillum and rhizobia or because of the interaction of Azospirillum and the plants themselves.

In this study, with the aim of finding further evidence that may elucidate the relative importance of the soybeanAzospirillum and Bradyrhizobium-Azospirillum interactions, we evaluated the effect of co-inoculating soybean seeds with BJE109 and AbAz39 at different ratios and interaction times. Both, in vivo and in planta assays were carried out to compare the performance between co-inoculation and single inoculation treatments with the bacterial strains on their own. The co-inoculation, combining Bradyrhizobium and Azospirillum strains, in a 1:1 proportion when treating the soybean seeds, represents the frequent co-inoculation treatment applied at farmers' fields. In this case, both strains are mixed and start their interaction with each other at the same time they are inoculated on the seeds. In this scenario, most of the effects of the presence of Azospirillum have direct impact on the plant. If the mix of microorganisms is prepared 24 hours before treating the seeds (T24), the strains interact with each other before reaching the seed coat and the derived benefits on nodulation and soybean growth could be interpreted from the effects of Azospirillum on Bradyrhizobium performance.

Because of its backbone contribution in the nitrogen nutrition of soybean plants, the main microorganism in the coinoculation mixture is $B J \mathrm{E} 109$. Initially, to analyze the physiological behavior of $B J \mathrm{E} 109$, we assessed different proportions of the combination with Azospirillum (1:9, 1:1 and 9:1). The 1:1 treatment was chosen because it had the greatest values of EPS production, bacterial biomass, and IAA degradation for which AbAz39 is responsible (Table S1). These parameters were selected with reference to previous studies published by our laboratory (Torres et al. 2018; 2021), in which we confirmed that exogenous IAA addition to pure BJE109 cultures triggered physiological changes in the bacterium, such as the ability to increase its biomass and produce EPS, both are advantages on the rhizobia cell survival on soybean seeds and on its symbiotic performance. We also obsserved that BJE109 can degrade IAA when is added to the culture medium through the action of a 3-phenylpropanoate dioxygenase-like enzyme (subunit alpha and beta) within a cluster named iac (Torres et al. 2018; 2021). This must be relevant for a better performance of the co-inoculation so the mix at T24 doubled the EPS content and significantly increased the biomass production in comparison to the T0 treatment (Table 1). In turn, T0 outperformed inoculation with BJE109 alone. An increase in the production of EPS by rhizospheric bacteria like rhizobia is related to higher plant tolerance to stress caused by water, oxidation, low temperature, and other factors (Cytryn et al. 2007; Chang and Halverson 2003; Tamaru et al. 2005). The exposure of $1 \mathrm{mM}$ IAA to $B$. diazoefficiens USDA110 increased the production of the EPS content, which also enhanced the plant tolerance to different types of stresses such as heat stress, cold stress, desiccation, among others (Donati et al. 2013). 
When the BjE109 survival was evaluated, the co-inoculation allowed recovering of more viable cells compared to the rest of treatments, being better in the T24 mix than in T0 (Table 2). The recovery kinetics for BjE109 on soybean seeds, assessed over time and under the conditions imposed by the different treatments, agreed with our previous results on the greater recovery of BjE109 and $B$. diazoefficiens USDA110 cells in cultures pre-incubated with IAA (Torres et al. 2018; Donati et al. 2013). These findings suggest that the production of IAA by AbAz29 in the culture medium of the mix may be partly responsible for the increase in EPS, which may offer BJE109 a better chance at surviving on the seeds. Auxins have long been posited to play a major role in nodule ontogenesis within legumerhizobium symbiosis (Thiman 1936), and there are many reports on alterations in nodule organogenesis due to changes in auxin content because of inoculation with auxin-producing bacteria or exogenous hormone addition (Schmidt et al. 1988). The co-inoculation with rhizobia and Azospirillum is not an exception. For example, coinoculation with IAA-deficient Sinorhizobium meliloti and IAA-producing A. brasilense on alfalfa generated significantly more nodules on the primary root (Schmidt et al. 1988). Remans et al. (2008) also provided direct evidence on the enhancing effects of IAA by co-inoculating beans with $R$. etli and a mutant IAA-deficient $A$. brasilense. The literature, then, might lead us to believe that the improvement observed in legume growth after inoculation with Azospirillum is explained by a hypothetical interaction between the bacteria and the plant, in which phytohormone synthesis (primarily IAA) could be crucial.

The co-inoculation could also favor AbAz39 performance that was conditioned by the interaction time. In this regard, it has been observed that the interaction of Bradyrhizobium with Azospirillum in soybeans seeds highly improved drought tolerance (Rondina et al. 2020) or enhanced the growth and yield of soybean plants under arsenic stress (Armendariz et al. 2019). This must be because the co-inoculation increased the number of nodules on the roots, leading to higher nodule biomass and thus improved BFN (Torres et al. 2018; Rondina et al. 2020). We not only corroborated these results but also demonstrated that an interaction time of $24 \mathrm{~h}$ prior inoculation improved the establishment of symbiosis, BNF and, as consequence, plant development under controlled (greenhouse) and uncontrolled growth conditions (field) compared to T0, and much more when the bacteria are used individually (Table 4 and 5). However, we also demonstrate that the number but not the size of the nodule influences the quality and quantity of the plant yield (Fig. 3). In the last decades, several authors have analyzed the contribution of coinoculation with Azospirillum sp. to legume productivity. In the pampas region (Argentina), 21 field trials performed on alfalfa showed that combined inoculation of Ensifer meliloti and A. brasilense was almost twice as effective as inoculation with rhizobia alone (Díaz-Zorita et al. 2012). Hungria et al. (2013) also reported increased yield for soybean and common bean when complementing seed inoculation with rhizobia with the in-furrow application of $A$. brasilense at four locations in Brazil. They found that inoculation of soybean with Bradyrhizobium resulted in an $8.4 \%$ increase in yield, against the $16.1 \%$ increase achieved by the combination of strains. For common beans, individual inoculation with $R$. tropici boosted yield by $8.3 \%$, but the addition of $A$. brasilense raised this figure to 19.6\%. A metadata analysis by Barbosa et al. (2021) revealed that soybean co-inoculation was related to a $2.8 \%$ increase in grain yield and a $3.2 \%$ increase in $\mathrm{N}$ concentration in the grains with respect to the inoculation only with Bradyrhizobium. In other 37 field trials, soybean co-inoculation with Bradyrhizobium and A. brasilense also increased mean yield by $227 \mathrm{~kg} \mathrm{ha}^{-1}$ with respect to the inoculation with Bradyrhizobium alone and by $335 \mathrm{~kg} \mathrm{ha}^{-1}$ with respect to the uninoculated control (Nogueira et al. 2018). Finally, co-inoculation of soybean was found to raise the nodulation percentage by around 5\% in Brazil (Hungria et al. 2015; Fipke et al. 2016; Galindo et al. 2018) and around 12\% in Argentina (Benintende et al. 2010; Ferraris and Couretot 2011, 2013; Morla et al. 2019), a difference which may be attributed to the tropical-subtropical and temperate conditions, respectively. Despite this, the limited dataset was insufficient to show a direct relationship between co-inoculation and changes in nodulation and grain yield. 


\section{Conclusions}

The findings presented here show that the pre-culture combining BJE109 and AbAz39 before the inoculation to the soybean seeds has benefits in plant nodulation and hence production, more than the single inoculation with $B j E 109$ or $A b A z 39$, or the immediate co-inoculation of both strains. The higher values for EPS production and rhizobium biomass obtained for this mix in its culture media mean that the rhizobium may be better able to survive on the seeds and establish symbiosis more successfully. This must be due to the beneficial effects on BjE109 growth and survival from the IAA produced by AbAz39. Consequently, the better bacteria performance, and its growth, have positive effects in planta with better growth and yield under controlled conditions, and also when are grown at dryland field conditions. The success in the co-inoculation with $B$. japonicum and $A$. brasilense, partially depends on the time that the microorganisms are allowed to interact prior inoculation. Further studies must be done in the future to understand not only the best conditions for co-inoculation of $B$. japonicum and $A$. brasilense, but also with other beneficial bacteria in which the pre-culture must be one of the most relevant points.

\section{Declarations}

\section{Acknowledgments}

To the Instituto de Investigaciones Agrobiotecnológicas (INIAB); Universidad Nacional de Río Cuarto (UNRC); Consejo Nacional de Investigaciones Científicas y Tecnológicas (CONICET), Fondo Nacional de Ciencia y Tecnología (FONCyT). FC is Researcher of CONICET at the UNRC. DT and GL are former Postdoc at the UNRC granted by CONICET. RM is Postdoc at the UNRC granted by CONICET. FD is a former PhD student at the UNRC granted by CONICET.

\section{References}

1. Armendariz AL, Talano MA, Nicotra MF, Escudero L, Breser ML, Porporatto C, Agostini E (2019) Impact of double inoculation with Bradyrhizobium japonicum E109 and Azospirillum brasilense Az39 on soybean plants grown under arsenic stress. Plant Physiol Biochem 138:26-35. https://doi.org/10.1016/j.plaphy.2019.02.018

2. Barbosa JZ, Hungria M, da Silva Sena JV, Poggere G, dos Reis AR, Corrêa RS (2021) Meta-analysis reveals benefits of co-inoculation of soybean with Azospirillum brasilense and Bradyrhizobium spp. in Brazil. Appl Soil Ecol 163:103913. https://doi.org/10.1016/j.apsoil.2021.103913

3. Bashan Y, De-Bashan LE (2010) How the plant growth-promoting bacterium Azospirillum promotes plant growth -a critical assessment. Adv Agron 108:77-136. https://doi.org/10.1016/S0065-2113(10)08002-8

4. Benintende S, UhrichW, HerreraM, Gangge F, Sterren M, Benintende M (2010) Comparación entre coinoculación con Bradyrhizobium japonicum y Azospirillum brasilense e inoculación simple con Bradyrhizobium japonicum en la nodulación, crecimiento y acumulación de $\mathrm{N}$ en el cultivo de soja. Agriscientia 27:71-77. https://doi.org/10.31047/1668.298x.v27.n2.2768

5. Bottini R, Fulchieri M, Pearce D, Pharis RP (1989) Identification of gibberellins A1, A3 and iso-A3 in cultures of Azospirillum lipoferum. Plant Physiol 90:45-47. https://doi.org/10.1104/pp.90.1.45

6. Bray RH, Kurtz LT (1945) Determination of total, organic, and available forms of phosphorus in soils. Soil Sci 59(1):39-46

7. Cacciari I, Lippi D, Pietrosanti T, Pietrosanti W (1989) Phytohormone-like substances produced by single and mixed diazotrophic cultures of Azospirillum and Arthrobacter. Plant soil 115(1):151-153. 
https://doi.org/10.1007/BF02220706

8. Cassán F et al (2020) Everything you must know about Azospirillum and its impact on agriculture and beyond. Biol Fertil Soils 56(4):461-479. https://doi.org/10.1007/s00374-020-01463-y

9. Cassán F, Díaz-Zorita M (2016) Azospirillum sp. in current agriculture: From the laboratory to the field. Soil Biol Biochem 103:117-130. https://doi.org/10.1016/j.soilbio.2016.08.020

10. Cassán F, Perrig D, Sgroy V, Masciarelli O, Penna C, Luna V (2009) Azospirillum brasilense Az39 and Bradyrhizobium japonicum E109, inoculated singly or in combination, promote seed germination and early seedling growth in corn (Zea mays L.) and soybean (Glycine max L.). Eur J Soil Biol 45:28-35. https://doi.org/10.1016/j.ejsobi.2008.08.005

11. Cassán F, Vanderleyden J, Spaepen S (2014) Physiological and agronomical aspects of phytohormone production by model plant growth-promoting rhizobacteria (PGPR) belonging to the genus Azospirillum. J Plant Growth Regul 33:440-459. https://doi.org/10.1007/s00344-013-9362-4

12. Crozier A, Arruda P, Jasmim JM, Monteiro AM, Sandberg G (1988) Analysis of indole-3-acetic acid and related indoles in culture médium from Azospirillum lipoferum and Azospirillum brasilense. Appl Environ Microbiol 54:2833-2837. https://doi.org/10.1128/AEM.54.11.2833-2837.1988

13. Deak EA, Martin TN, Fipke GM, Stecca JDL, Cunha VDS (2020) Soil humidity as a productive conditioner of soybean culture through inoculation, co-inoculation and rooting. Aust J Crop Sci 14(6):932-939. https://search.informit.org/doi/10.3316/informit.317412684009889

14. Díaz-Zorita M, Baliña RM, Fernández Canigia MV (20129. Azospirillum brasilense enhances alfalfa productivity: field evaluation. 9th International and 1st Latinamerican PGPR Workshop. "Returning to our roots". Quirama, Medellín (Colombia), p. 75

15. Donati A, Lee H, Leveau J, Chang W (2013) Effects of indole-3-acetic acid on the transcriptional activities and stress tolerance of Bradyrhizobium japonicum. PLoS ONE 8(10). https://doi.org/10.1371/journal.pone.0076559

16. dos Santos FL, da Silva FB, de Sá ELS, Vian AL, Muniz AW, dos Santos RN (2019) Inoculation and co-inoculation of growth promoting rhizobacteria in irrigated rice plants. Revista Brasileira de Ciências Agrárias 14(3):1-5. https://doi.org/10.5039/agraria.v14i3a5665

17. Ferraris $G$, Couretot $L$ (2011) Interacción entre microorganismos fijadores de nitrógeno y promotores de crecimiento (PGPM) en soja. I. Bradyrhizobium japonicum y Azospirillum brasilense: efectos sobre la nodulación el rendimiento y su interacción con prácticas de manejo. INTA EEA Pergamino Desarrollo RuralUnidad Territorial Agricola. Campaña 2010/11

18. Ferraris G, Couretot L (2013) Evaluación de tratamientos biológicos con Bradyrhizobium japonicum y Azospirillum brasilense en soja: efectos sobre la fijación de nitrógeno y el rendimiento. INTA EEA Pergamino Desarrollo Rural-Unidad Territorial Agrícola. Campaña 2012/13

19. Ferri GC, Braccini AL, Anghinoni FBG, Pereira LC (2017) Efects of associated co-inoculation of Bradyrhizobium japonicum with Azosprillum brasilense on soybean yield and growth. Afr J Agric Res 12:6-11. https://doi.org/10.5897/AJAR2016.11711

20. Fipke GM, Conceição GM, Grando LFT, Ludwig RL, Nunes UR, Martin TN (2016) Co-inoculation with diazotrophic bacteria in soybeans associated to urea topdressing. Cienc Agrotec 40:522-533. https://doi.org/10.1590/141370542016405001316

21. Galindo FS, Teixeira Filho M, Buzetti S, Ludkiewicz MG, Rosa PA, Tritapepe CA (2018) Technical and economic viability of coinoculation with Azospirillum brasilense in soybean cultivars in the Cerrado. Rev Bras Eng Agr Amb 22:51-56. https://doi.org/10.1590/1807-1929/agriambi.v22n1p51-56

Page $16 / 21$ 
22. Glickmann E, Dessaux Y (1995) A critical examination of the specificity of the salkowski reagent for indolic compounds produced by phytopathogenic bacteria. Appl Environ Microbiol 61(2):793e6.

https://doi.org/10.1128/AEM.61.2.793-796.1995

23. Hoagland D, Broyer $T$ (1936) General nature of the process of salt accumulation by roots with description of experimental methods. Plant Physiol 11(3):471. https://doi.org/10.1104/pp.11.3.471.. 471e507

24. Horemans S, de Koninck K, Neuray J, Hermans R, Valassak K (1986) Production of plant growth substances by Azospirillum sp. and other rhizosphere bacteria. Symbiosis 2:341-346

25. Hungria M, Nogueira MA (2019) Tecnologias de inoculação da cultura da soja: Mitos, verdades e desafios. Boletim de Pesquisa 2019/2020. Fundação MT, Rondonópolis, pp 50-62. (Fundação MT. Boletim, 19)

26. Hungria M, Nogueira MA, Araujo RS (2013) Co-inoculation of soybeans and common beans with rhizobia and azospirilla: strategies to improve sustainability. Biol Fertil Soils 49:791-801. https://doi.org/10.1007/s00374012-0771-5

27. Hungria M, Nogueira MA, Araujo RS (2015) Soybean seed co-inoculation with Bradyrhizobium spp. and Azospirillum brasilense: a new biotechnological tool to improve yield and sustainability. Am J Plant Sci 6:811817. https://doi.org/10.4236/ajps.2015.66087

28. Jaiswal SK, Mohammed M, Ibny FYI, Dakora FD (2021) Rhizobia as a Source of Plant Growth-Promoting Molecules: Potential Applications and Possible Operational Mechanisms. Front Sustain Food Syst 4:619676. https://doi.org/10.3389/fsufs.2020.619676

29. Janzen RA, Rood SB, Dormaar JF, McGill WB (1992) Azospirillum brasilense produces gibberellin in pure culture on chemically defined medium and in co-culture on straw. Soil Biol Biochem 24:1061-1064. https://doi.org/10.1016/0038-0717(92)90036-W

30. Lindsay W, Norvell W (1978) Development of a DTPA soil test for zinc, iron, manganese, and copper. Soil Sci Soc Amer J 42:421-428

31. Lodeiro AR (2015) Interrogantes en la tecnología de la inoculación de semillas de soja con Bradyrhizobium spp [Queries related to the technology of soybean seed inoculation with Bradyrhizobium spp]. Rev Argent Microbiol 47(3):261-73 https://doi.10.1016/j.ram.2015.06.006

32. Markwell J, Osterman JC, Mitchell JL (1995) Calibration of the Minolta SPAD-502 leaf chlorophyll meter. Photosynth Res 46:467-472. https://doi.org/10.1007/BF00032301

33. Miles B, Misra SJJ, Irwin JO (1938) The estimation of the bactericidal power of the blood Epidemiol. Infect 38:732-732. https://doi.org/10.1017/S002217240001158X

34. Molina R, López G, Rodríguez B, Rosas S, Mora V, Cassán F (2020) Evaluation of growth and motility in nonphotosynthetic Azospirillum brasilense exposed to red, blue, and white light. Arch Microbiol 1-9. https://doi.org/10.1007/s00203-020-01829-8

35. Molina R, Rivera D, Mora V, López G, Rosas S, Spaepen S, Vanderleyden J, Cassán F (2018) Regulation of IAA biosynthesis in Azospirillum brasilense under environmental stress conditions. Curr Microbiol 75:1408-1418. https://doi.org/10.1007/s00284-018-1537-6

36. Molla AH, Shamsuddin ZH, Halimi MS, Morziah M, Puteh AB (2001) Potential for enhancement of root growth and nodulation of soybean co-inoculated with Azospirillum and Bradyrhizobium in laboratory systems. Soil Biol Biochem 33(4-5):457-463. https://doi.org/10.1016/S0038-0717(00)00186-3

37. Moretti LG et al (2020) Effects of growth-promoting bacteria on soybean root activity, plant development, and yield. Agron J 112(1):418-428. https://doi.org/10.1002/agj2.20010 
38. Morla FD, Cerioni GA, Giayetto O, Tello RD, Pelizza NA, Baliña R (2019) Evaluación de la co-inoculación en soja con Bradyrhizobium japonicum y Azospirillum brasilense. $7^{\circ}$ Congreso de la Soja del MERCOSUR (MERCOSOJA 2019)

39. Nogueira MA, Prando AM, Oliveira AB, Lima D, Conte O, Harger N, Oliveira FT, Hungria M (2018) Ações de transferência de tecnologia em inoculação/ coinoculação com Bradyrhizobium e Azospirillum na cultura da soja na safra 2017/18 no estado do Paraná, vol 15. Embrapa Soja. (Embrapa Soja. Circular Técnica, 143). ISSN 1516-7860 https://www.embrapa.br/busca-de-publicacoes/-/publicacao/1095314/acoes-de-transferencia-detecnologia-em-inoculacaocoinoculacao-com-bradyrhizobium-e-azospirillum-na-cultura-da-soja-na-safra-201718no-estado-do-parana Londrina

40. Nogueira MA, Prando AM, Oliveira AB, Lima DD, Conte O, Harger N, Oliveira FT, Hungria M (2018) Açoes de transferencia de tecnologia em inoculaçao/coinoculaçao com Bradyrhizobium e Azospirillum na cultura da soja na safra 2017/18 no estado do Paraná. Embrapa Soja, Londrina, (Circular Técnica, 143).

https://www.embrapa.br/busca-de-publicacoes/-/publicacao/1095314/acoes-de-transferencia-de-tecnologiaem-inoculacaocoinoculacao-com-bradyrhizobium-e-azospirillum-na-cultura-da-soja-na-safra-201718-no-estadodo-parana

41. Penna C, Massa R, Olivieri F, Gutkind G, Cassán F (2011) A simple method to evaluate the number of bradyrhizobia on soybean seeds and its implication on inoculant quality control. AMB Express 1:21. https://doi.org/10.1186/2191-0855-1-25

42. Perrig D, Boiero ML, Masciarelli OA, Penna C, Ruiz OA, Cassán FD, Luna MV (2007) Plant-growth-promoting compounds produced by two agronomically important strains of Azospirillum brasilense, and implications for inoculant formulation. Appl Microbiol Biotechnol 75:1143-1150. https://doi.org/10.1007/s00253-007-0909-9

43. Queiroz Rego CH, Cardoso FB, da Silva Cândido AC, Teodoro PE, Alves CZ (2018) Co-inoculation with Bradyrhizobium and Azospirillum Increases Yield and Quality of Soybean Seeds. Agron J 110(6):2302-2309. https://doi.org/10.2134/agronj2018.04.0278

44. Remans R, Beebe S, Blair M et al (2008) Physiological and genetic analysis of root responsiveness to auxinproducing plant growth-promoting bacteria in common bean (Phaseolus vulgaris L.). Plant Soil 302:149-161. https://doi.org/10.1007/s11104-007-9462-7

45. Ritchie SW, Hanway JJ, Thompson HE, Benson GO (1994) How a soybean plant develops. Cooperative Extension, lowa State University, Ames, lowa. Special Report No. 53. 20 pp

46. Rivera Botia D et al (2014) Complete genome sequence of the model rhizosphere strain Azospirillum brasilense Az39, successfully applied in agriculture. Genome Announc 2:0683-0614.

https://doi.org/10.1128/genomeA.00683-14

47. Rivera D, Mora V, López G, Rosas S, Spaepen S, Vanderleyden J, Cassán F (2018) New insights into indole-3acetic acid metabolism in Azospirillum brasilense. J Appl Microbiol 125:1774-1785.

https://doi.org/10.1111/jam.14080

48. Rodelas B, González-López J, Martínez-Toledo MV, Pozo C, Salmerón V (1999) Influence of Rhizobium/ Azotobacter and Rhizobium/ Azospirillum combined inoculation on mineral composition of faba bean (Vicia faba L.). Biol Fertil Soils 29(2):165-169. https://doi.org/10.1007/s003740050540

49. Rodríguez Cáceres EA (1982) Improved medium for isolation of Azospirillum spp. Appl Environ Microbiol 44:990-991

50. Rondina ABL, dos Santos Sanzovo AW, Guimarães GS, Wendling JR, Nogueira MA, Hungria M (2020) Changes in root morphological traits in soybean co-inoculated with Bradyrhizobium spp. and Azospirillum brasilense or 
treated with A. brasilense exudates. Biol Fertil Soils 1-13. https://doi.org/10.1007/s00374-020-01453-0

51. Schmidt J, Wingender R, John M, Wieneke U, Schell J (1988) Rhizobium meliloti nodA and nodB genes are involved in generating compounds that stimulate mitosis of plant cells. PNAS 85(22):8578-8582. https://doi.org/10.1002/j.1460-2075.1988.tb02850.x

52. Srinivasan M, Holl F, Petersen D (1996) Influence of indoleacetic-acid-producing Bacillus isolates on the nodulation of Phaseolus vulgaris by Rhizobium etli under gnotobiotic conditions. Can J Microbiol 42(10):10061014. https://doi.org/10.1139/m96-129

53. Stacey G, Burris R, Evans H (1992) Biological nitrogen fixation. Springer

54. Thimann KV (1936) On the physiology of the formation of nodules on legume roots. Proc Natl Acad Sci USA 22(8):511e4. https://doi.org/10.1073/pnas.22.8.511

55. Torres D et al (2015) Genome Sequence of Bradyrhizobium japonicum E109, One of the Most Agronomically Used Nitrogen-Fixing Rhizobacteria in Argentina. Genome Announc 3(1):e01566-e01514. https://doi.org/10.1128/genomeA.01566-14

56. Torres D et al (2018) New insights into auxin metabolism in Bradyrhizobium japonicum. Res Microbiol 169(6):313-323. https://doi.org/10.1016/j.resmic.2018.04.002

57. Torres D et al (2021) Molecular and physiological analysis of indole-3-acetic acid degradation in Bradyrhizobium japonicum E109. Res Microbiol 172(3). https://doi.org/10.1016/j.resmic.2021.103814

58. Vessey JK, Buss TJ (2002) Bacillus cereus UW85 inoculation effects on growth, nodulation, and N accumulation in grain legumes: controlled-environment studies. Can J Plant Sci 82(2):282-290. https://doi.org/10.4141/P01047

59. Vincent JA (1970) Manual for the practical study of root-nodul bacteria. Int Biol Program Handb, Blackwell, Oxford. https://doi.org/10.1093/nar/gki106

60. Zimmer W, Bothe H (1988) The phytohormonal interactions between Azospirillum and wheat. Plant soil 110(2):239-247. https://doi.org/10.1007/BF02226804

\section{Figures}




\section{B. japonicum E109}

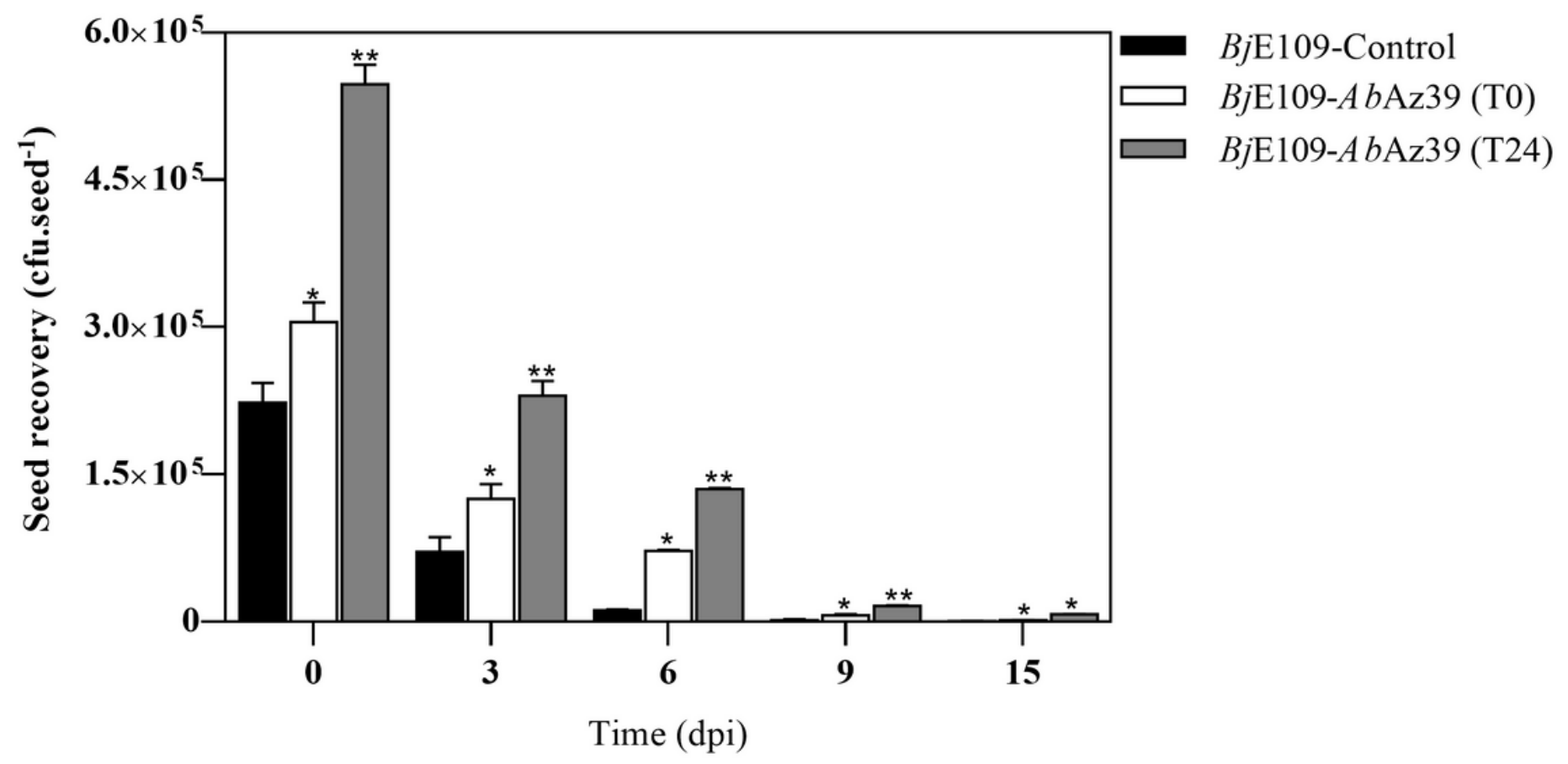

Figure 1

Time-dependent cell recovery ( $\log 10 \mathrm{cfu}$.seed-1) of BjE109 on soybean seeds inoculated individually or in combination with AbAz39 (1:1) after $15 \mathrm{~m}$ (T0) or $24 \mathrm{~h}$ (T24) of interaction. Asterisks represent significant differences between treatments according to Tukey test $p<0.05$.
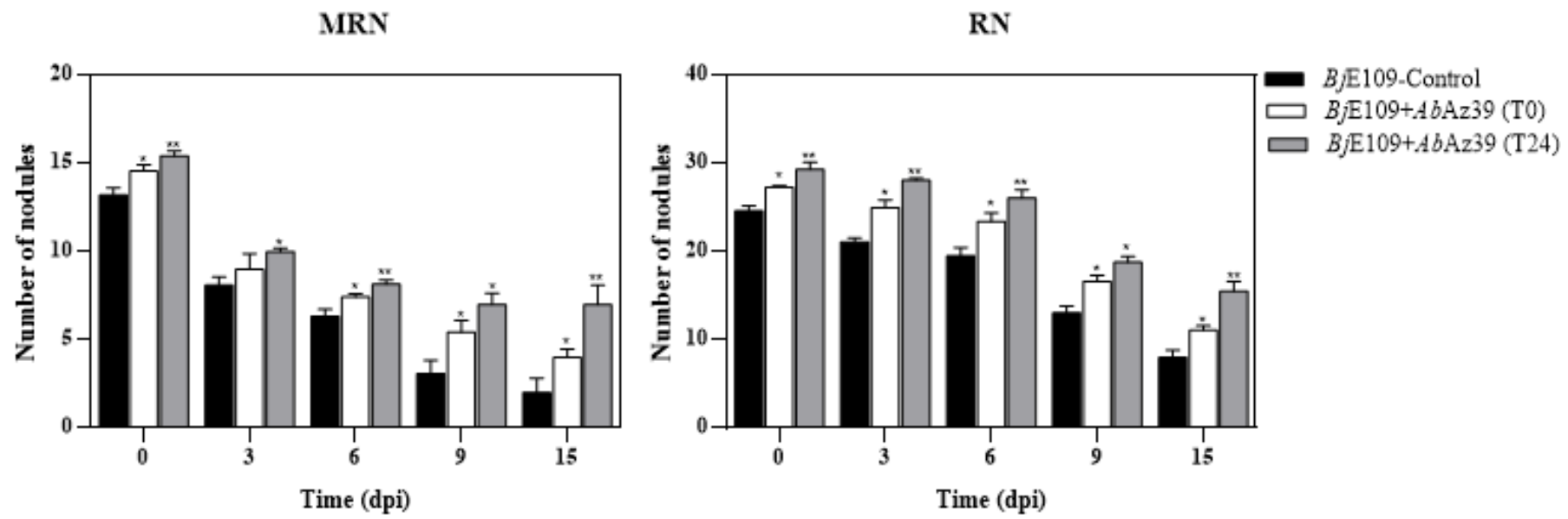

Figure 2

Time-dependent nodulation on soybean roots on different days post-inoculation (dpi) with BjE109 or AbAz39 individually (control) or their combination (1:1) after $15 \mathrm{~min}$ (T0) or $24 \mathrm{~h}$ (T24) of interaction. Asterisks represent significant differences according to Tukey test $\mathrm{p}<0.05$. References: MNR: main root nodulation; RN: root nodulation 


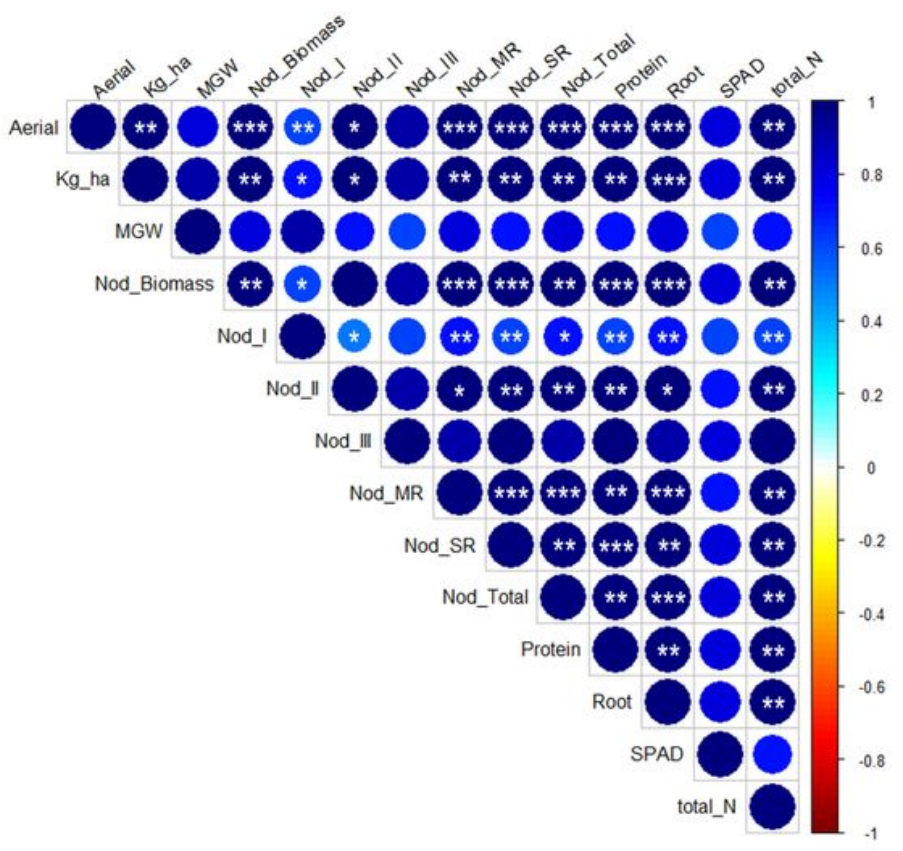

Figure 3

Matrix correlation between nodulation and plant production related parameters of soybean plants from seed uninoculated, inoculated with either BjE109 or AbAz39, individually, or the combination of both at T0 or T24 according to Pearson correlation. Red asterisks indicate significant correlations. P > 0.05 *; P > 0.01 **; P > 0.001 ***

\section{Supplementary Files}

This is a list of supplementary files associated with this preprint. Click to download.

- Torresetal.2021TableS1.docx 